\title{
PENERAPAN MODEL CONTEXTUAL TEACHING AND LEARNING (CTL) UNTUK MENINGKATKAN KEMAMPUAN BERPIKIR KRITIS MATEMATIS SISWA BERBANTUAN APLIKASI GEOMETRY CALCULATOR
}

\author{
Dosmaroha Samosir \\ Universitas Katolik Santo Thomas, Medan; \\ samosirdosmaroha@gmail.com
}

\begin{abstract}
Abstrak. Penelitian ini bertujuan untuk mengetahui peningkatan kemampuan berpikir kritis matematis siswa melalui penerapan model pembelajaran Contextual Teaching and Learning (CTL) berbantuan aplikasi geometry calculator pada materi segiempat dan segitia pada kelas VII SMP Budi Murni 1Medan. Jenis penelitian ini adalah Penelitian Tindakan Kelas (PTK). Subjek penelitian yaitu siswa kelas VII SMP Budi Murni 1 Medan dengan jumlah siswa 26 orang. Objek penelitian adalah peningkatan kemampuan berpikir kritis matematis siswa dengan menerapkan model contextual teaching and Learning (CTL) berbantuan aplikasi geometrycalculator. Teknik pengumpulan data yang digunakan yaitu observasi dan tes. Observasi terdiri dari observasi guru dan observasi siswa. Tes yang diberikan yaitu tes kemampuan awal, tes kemampuan berpikir kritis matematis siswa siklus I dan tes kemampuan berpikir kritis matematis siswa siklus II. Hasil analisis data siklus I diperoleh observasi aktivitas guru 65\% baik, observasi aktivitas siswa dengan nilai $61 \%$ (baik). Pada siklus I siswa yang sudah mencapai KKM 14 orang (53,84\%) sedangkan yang belum mencapai KKM adalah 12 orang (46,16\%). Nilai rata-rata siswa pada siklus I adalah 55,03. Jumlah siswa yang tuntas secara klasikal belum mencapai $75 \%$, maka dilanjutkan pada siklus II. Hasil observasi aktivitas guru pada siklus II dengan persentase $83,5 \%$ (baik sekali), observasi aktivitas siswa dengan persentase $81,5 \%$ (baik sekali) dan siswa yang sudah mencapai KKM adalah 23 orang $(88,46 \%)$, siswa yang tidak mencapai mencapai KKM adalah 3 orang $(11,54 \%)$ dan nilia rata-rata siswa pada siklus II adalah 77,50 . Berdasarkan analisis data dapat disimpulkan bahwa penerapan model pembelajaran Contextual Teaching and Learning (CTL) berbantuan aplikasi geometry calculator dapat meningkatakan kemampuan berpikir kritis matematis siswa pada materi segiempat dan segitiga di kelas VII SMP Budi Murni 1 Medan.
\end{abstract}

Cartesius: Jurnal Pendidikan Matematika Vol. 3, No. 1

CProdi Pendidikan Matematika Universitas Katolik Santo Thomas 
Kata Kunci. Berpikir kritis, CTL, Geometry Calculator.

\begin{abstract}
This study aims to determine the improvement of students' mathematical critical thinking skills through the application of the Contextual Teaching and Learning (CTL) learning model assisted by the application of geometry calculator on quadrilateral and committee material in class VII Budi Murni 1Medan Middle School. This type of research is Classroom Action Research (CAR). The subjects of the study were Grade VII students of SMP Budi Murni 1 Medan with 26 students. The object of research is to increase students' mathematical critical thinking skills by applying a contextual teaching and learning (CTL) model assisted by the application of geometrycalculator. Data collection techniques used are observation and tests. Observation consists of teacher observation and student observation. The tests that were given were the initial ability test, the first cycle mathematical critical thinking ability test students and the second cycle mathematical critical thinking ability test. The results of the first cycle of data analysis obtained observations $65 \%$ good teacher activity, observation of student activities with a value of $61 \%$ (good). In the first cycle students who have reached KKM 14 people $(53.84 \%)$ while those who have not reached KKM are 12 people $(46.16 \%)$. The average value of students in the first cycle is 55.03. The number of students who finished classically has not reached $75 \%$, then continued in cycle II. The results of observations of teacher activities in the second cycle with a percentage of $83.5 \%$ (excellent), observation of student activities with a percentage of $81.5 \%$ (excellent) and students who have reached KKM are 23 people $(88.46 \%)$, students who do not reaching the KKM is 3 people $(11.54 \%)$ and the average value of students in the second cycle is 77.50. Based on data analysis, it can be concluded that the application of the Contextual Teaching and Learning (CTL) learning model assisted by the application of geometry calculator can improve students' mathematical critical thinking skills on rectangular and triangular material in class VII Budi Murni 1 Medan Middle School.
\end{abstract}

Keywords. Critical thinking, CTL, Geometry Calculator.

\title{
PENDAHULUAN
}

Pendidikan matematika mempunyai peranan yang sangat penting dalam mempersiapkan sumber daya manusia yang lebih berkualitas di masa yang akan datang. Pendidikan matematika sangat erat kaitannya dengan pembelajaran matematika. Pembelajaran matematika dapat menolong siswa

Cartesius: Jurnal Pendidikan Matematika Vol. 3, No. 1

CProdi Pendidikan Matematika Universitas Katolik Santo Thomas 
dalam pembentukan karakternya atau kepribadianya lewat berbagai cara. Oleh karena itu, matematika perlu untuk diajarkan mulai dari tingkat sekolah dasar hingga tingkat perguruan tinggi. Mengingat pentingnya pendidikan matematika dalam kehidupan sehari hari, maka pembelajaran matematika merupakan hal yang paling penting untuk diperhatikan. Pada pembelajaran matematika diharapkan tidak hanya mengajarkan fakta dan konsep, tetapi juga harus membekali peserta didik dalam bernalar, memecahkan masalah yang dialami dalam kehidupan sehari-hari. Hal tersebut sesuai KTSP (2006) yang disempurnakan pada kurikulum 2013 (dalam Soemarmo, 2014: 7) yang mencantumkan tujuan pembelajaran matematika adalah sebagai berikut:

1. Memahami konsep matematika, menjelaskan keterkaitan antar konsep, dan mengaplikasikan konsep atau algoritma secara luwes, akurat, efisien, dan tepat pada pemecahan masalah.

2. Menggunakan penalaran pada pola dan sifat, melakukan manipulasi matematika dalam generelisasi, menyusun bukti, atau menjelaskan gagasan dan pernyataan matematika.

3. Memecahkan masalah yang meliputi kemampuan memahami masalah, merancang model matematika, menyelesaikan model, dan menafsirkan solusi yang diperoleh.

4. Mengkomunikasikan gagasan dengan simbol, tabel, diagram, ataupun media lain untuk memperjelas keadaan masalah.

5. Memiliki sikap menghargai penggunaan matematika dalam kehidupan yaitu memiliki rasa ingin tahu, perhatian, dan minat dalam mempelajari matematika, serta sikap ulet dan percaya diri dalam pemecahan masalah.

Pada kenyataannya pembelajaran matematika yang berlangsung selama ini belum mencapai tujuan pembelajaran yang diharapakan. Hal ini juga terjadi pada siswa kelas VII SMP Budi Murni 1 Medan. Berdasarkan data yang diperoleh dari SMP Budi Murni 1 Medan bahwa hasil belajar matematika siswa rendah. Hal tersebut dapat dilihat dari hasil ujian bulanan dari beberapa kelas pada pelajaran matematika Tahun Ajaran 2018/2019 pada tabel berikut:

Cartesius: Jurnal Pendidikan Matematika Vol. 3, No. 1

CProdi Pendidikan Matematika Universitas Katolik Santo Thomas 
Tabel 1. Nilai Formatif Siswa Kelas VII Tahun 2018/2019

\begin{tabular}{|c|c|c|c|c|c|}
\hline \multirow{2}{*}{ No. } & \multirow{2}{*}{ Kelas } & \multirow{2}{*}{ Jumlah Siswa } & \multicolumn{2}{|c|}{ Pencapaian KKM } & \multirow[t]{2}{*}{ KKM } \\
\hline & & & Tuntas & Tidak Tuntas & \\
\hline 1 & VII-A & 26 & 7 & 19 & \multirow{5}{*}{70} \\
\hline 2 & VII-B & 27 & 5 & 22 & \\
\hline 3 & VII-C & 27 & 3 & 24 & \\
\hline 4 & VII-D & 30 & 4 & 26 & \\
\hline & otal & 110 & $17(15 \%)$ & $93(85 \%)$ & \\
\hline
\end{tabular}

Sumber: SMP Budi Murni 1 Medan Tahun Ajaran 2018/2019

Dimanabahwa hasil ujian bulanan matematika SMP Budi Murni 1 Medan 85\% siswa tidak mencapai KKM yang telah di tetapkan yaitu 70. Berdasarkan hasil wawancara calon peneliti dengan guru matematika yaitu bapak Sinabariba beliau menyatakan bahwa proses pembelajaran matematika yang berlangsung masih kurang baik. Hal ini disebabkan karena proses pembelajaran matematika konvensional yang berpusat pada guru (Teacher Centered) guru masih cenderung menyampaikan materi dengan metode ceramah, media pembelajaran yang digunakan masih kurang, pertanyaan jarang muncul, siswa kurang aktif dalam proses pembelajaran, hal ini mengakibatkan proses pembelajaran menjadi pasif. Oleh karena itu, siswa belum terbiasa untuk mengidentifikasi atau merumuskan permasalahan ke dalam model matematika, siswa belum terbiasa memberikan langkah penyelesaian masalah, dan siswa belum terbiasa untuk memilih strategi pemecahan masalah untuk menghasilkan kesimpulan yang benar dan tepat.

Dalam mempelajari ilmu matematika kemampuan berpikir tingkat tinggi menjadi yang utama karena ilmu matematika memuat konsep-konsep abstrak yang unsur-unsurnya tidak terdefenisikan. Hal ini sejalan dengan kurikulun 2013 yang menuntut siswa untuk memiliki kemampuan berpikir tingkat tinggi agar siswa mampu menginterpretasikan, menganalisa informasi dengan baik. Oleh sebab itu kemampuan berpikir tingkat tinggi pada siswa perlu dikembangkan dalam proses pembelajaran khususnya dalam pembelajaran matematika, dimana salah satunya adalah berpikir kritis. kemampuan berpikir kritis merupakan suatu proses penggunaan

Cartesius: Jurnal Pendidikan Matematika Vol. 3, No. 1

CProdi Pendidikan Matematika Universitas Katolik Santo Thomas 
kemampuan berpikir secara rasional dan reflektif. Hal ini sehubungan dengan yang dikemukakan oleh Sumakim (dalam Novtiar dan Aripin, 2017:120) yang mengatakan bahwa keterampilan berpikir kritis matematis sangat penting bagi siswa karena dengan keterampilan ini siswa mampu bersikap rasional dan memilih alternatif pilihan yang terbaik bagi dirinya.

Berdasarkan minitest yang telah dilakukan di kelas VII-A di SMP Swasta Katolik Budi Murni 1 Medan pada tanggal 29 Januari 2019 pada materi segiempat dan segitiga, banyak siswa masih kesulitan dalam menjawab soal yang diberikan. Adapun soal dan penyelesaian minites kemampuan berpikir kritis matematis siswa adalah sebagai berikut:

Berdasarkan hasil minites kemampuan berpikir kritis matematis siswa pada materi segiempat dan segitiga soal nomor 1 berikut kesimpulan jawaban siswa soal nomor 1 terlihat bahwa siswa, tidak mempunyai keterampilan dasar penyelesaian segiempat dan segitiga. Secara menyeluruh 17 siswa (65\%) tidak mampu menjawab soal dengan baik, dan 9 siswa (35\%) siswa mampu menjawab soal dengan baik tetapi proses penyelesaianya belum tepat.

Berdasarkan hasil minites kemampuan berpikir kritis matematis siswa pada materi segiempat dan segitiga pada soal nomor 2terlihat jelas bahwa siswa tidak mampu memahami pertanyaan dari soal yang diberikan. Pertanyaan dari soal ini adalah bagaimana ukuran $\angle P Q R S$ dan $\angle Q R P$ dari persegi tersebut. Namun terlihat jelas 18 siswa (69\%) belum mampu mendefenisikan dan menyimpulkan soal dan 8 siswa (31\%) dapat mendefenisikan dan menyimpulkan soal akan tetapi proses penyelesaiannya belum tepat.

Berdasarkan hasil minites kemampuan berpikir kritis matematis siswa pada materi segiempat dan segitiga soal nomor 3 terlihat jelas bahwa 17 siswa (65\%) siswa tidak memahami strategi dan taktik mengerjakan soal. Ada 9 siswa (35\%) dapat memahami strategi dan taktik mengerjakan soal namun tidak sepenuhnya benar. Berdasarkan hasil minites di atas dapat ditarik kesimpulan bahwa kemampuan berpikir kritis matematis siswa rendah.

Cartesius: Jurnal Pendidikan Matematika Vol. 3, No. 1

CProdi Pendidikan Matematika Universitas Katolik Santo Thomas 
Sehubungan dengan hal tersebut, maka penting dilakukan perbaikan proses belajar mengajar dalam mendorong peningkatan kemampuan berpikir kritis matematis siswa. Perbaikan proses belajar melalui upaya yang dilakukan adalah menerapkan model pembelajaran yang dekat dengan kehidupan siswa sehari-hari salah satu model pembelajaran untuk meningkatkan kemampuan berpikir kritis siswa adalah Contextual Teaching and Leraning (CTL).

Pembelajaran CTL merupakan pembelajaran yang mengaitkan materi dengan dunia nyata. Hal ini sehungan dengan yang dikemukakan oleh Trianto (dalam Wakijo 2016: 44) bahwa Contextual Teaching and Learning (CTL) merupakan konsep belajar membantu guru mengaitkan materi yang diajarkan dengan situasi dunia nyata siswa dan mendorong siswa membuat hubungan antara pengetahuan yang dimilikinya dengan penerapannya dalam kehidupan sehari-hari.

Model pembelajaran CTL pada tahap konstruktivisme akan mengakibatkan proses pembelajaran berpusat pada siswa (Student Center) sehingga siswa dituntut aktif saat proses pembelajaran berlangsung. Pada tahap inquiry siswa akan terbiasa memberikan langkah-langkah penyelesaian masalah. Tahap learning community siswa akan terbiasa saling Tanya jawab. Pada tahap modeling siswa terbiasa untuk mengidentifikasi atau merumuskan permasalahan ke dalam model matematika, tahap refleksion siswa terbiasa memilih strategi pemecahan masalah untuk menghasilkan kesimpulan yang tepat.

Mengingat perkembangan ICT yang semakin pesat di era revolusi industri 4.0 maka sebaiknya dalam pembelajaran matematika media yang digunakan adalah berbasis android, salah satunya adalah Geometry calculator. Geometry calculator adalah aplikasi yang membuat perhitungan menjadi lebih cepat dan mudah untuk memperoleh jawaban yang benar. Penggunaan media pembelajaran dengan menggunakan geometry calculator diharapkan dapat direspon positif oleh siswa dan mampu, dengan menggunakan model kontekstual untuk meningkatkan kemampuan berpikir kritis.

Cartesius: Jurnal Pendidikan Matematika Vol. 3, No. 1

CProdi Pendidikan Matematika Universitas Katolik Santo Thomas 
Berdasarkan uraian di atas, maka model pembelajaran Contextual Teaching and Learning (CTL) berbantuan Geometry Calculator merupakan salah satu solusi untuk meningkatkan kemampuan berpikir kritis matematis siswa. Oleh karena itu, perlu dilakukan penelitian terkait dengan Penerapan Model Contextual and Teaching and Learning (CTL) Untuk Meningkatkan Kemampuan Berpikir Kritis Siswa Kelas VII SMP Budi Murni 1 Medan Pada Materi Segitiga dan Segiempat Berbantuan Geometry Calculator Tahun Ajaran 2018/2019.

\section{METODE}

Metode penelitian yang digunakan yaitu penelitian tindakan kelas. Menurut Tampubolon (2014: 19) menyatakan bahwa penelitian tindakan kelas adalah penelitian yang dilaksanakan oleh pendidik/calon guru di ruangan kelasnya sendiri secara kolaboratif/partisipatif untuk memperbaiki kinerja pendidik menyangkut kualitas proses pembelajaran, dan meningkatkan hasil belajar peserta didik menyangkut kualitas proses pembelajaran, dan meningkatkan hasil belajar peserta didik, baik dari aspek akademik maupun nonakademik, melalui tindakan reflektif dalam bentuk siklus. Dapat disimpulkan bahwa Penelitian Tindakan Kelas adalah penelitian yang dilakukan oleh pendidik atau calon pendidik dalam proses pembelajaran di dalam kelas yang dapat meningkatkan hasil belajar siswa.

Pada penelitian tindakan kelas ini diharapkan dapat meningkatkan kualitas siswa baik dalam aspek pemahaman, maupun aspek-aspek lain yang bermanfaat bagi siswa untuk menjadi dewasa seutuhnya. Adapun prosedur penelitian tindakan kelas dengan model Kemmis dan McTaggart yang terdiri dari perencanaan tindakan (planning), pelaksanaan tindakan (acting), observasi (observing), dan refleksi (reflecting) Saur (2013 : 27). Dalam penelitian ini menggunakan penelitian kolaboratif yaitu guru bersama peneliti berkolaborasi dalam melakukan penelitian tindakan kelas ini.

Subjek pada penelitian ini yaitu siswa kelas VII-A SMP Swasta Budi Murni1 Medan tahun pelajaran 2018/2019 yang terdiri dari 26 siswa yaitu laki-laki 8 orang dan perempuan 26 orang. Objek penelitian ini adalah menerapkan

Cartesius: Jurnal Pendidikan Matematika Vol. 3, No. 1

CProdi Pendidikan Matematika Universitas Katolik Santo Thomas 
model Contextual Teaching and Learning (CTL) berbantuan geometry calculator dan kemampuan berpikir kritis matematis.

Teknik pengumpulan data yang digunakan calon peneliti pada penelitian ini adalah tes dan non-tes. Teknik tes dalam penelitian ini menggunakan tes awal dan tes kemampuan berpikirkritismatematispada setiap siklus. Soal tes berbentuk uraian sebanyak 5 soal disusun sesuai indikator kemampuan pemberpikirkritismatematis. Selanjutnya, teknik non-tes yang dimaksud pada penelitian ini menggunakan lembar observasi aktivitas guru dan siswa.

\section{HASIL DAN PEMBAHASAN}

Hasil tes siswa pada tes awal, siklus I dan tes siklus II setiap tes diberikan 5 soal uraian, pada setiap soal terdapat indikator kemampuanberpikirkritismatematissiswa. Secara keseluruhan hasil perolehan nilai rata - rata siswa pada tes awal, siklus I, tes siklus II dapat pada tabel berikut:

Tabel 2. Tingkat Kemampuan Berpikir Kritis Matematis

\begin{tabular}{lccc}
\hline \multicolumn{1}{c}{ Kategori } & Tes Awal & Tes Siklus I & $\begin{array}{c}\text { Tes Siklus } \\
\text { II }\end{array}$ \\
\hline Nilai Terendah & 10 & 20 & 40 \\
\hline Nilai Tertinggi & 82 & 85 & 100 \\
\hline Jumlah Siswa yang Tuntas & 6 Siswa & 14 Siswa & 23 Siswa \\
\hline $\begin{array}{l}\text { Jumlah Siswa yang Tidak } \\
\text { Tuntas }\end{array}$ & 20 Siswa & 12 Siswa & 3 Siswa \\
\hline Rata-Rata & 43,07 & 55,03 & 77,50 \\
\hline Ketuntasan Klasikal & $23,07 \%$ & $53,84 \%$ & $88,46 \%$ \\
\hline
\end{tabular}

Dari tabel 2 dapat dilihat bahwa terjadi peningkatan yang diperoleh siswa dari tes awal, tes siklus I sampai tes siklus II. Pada nilai terendah siswa dan nilai tertinggi siswa adanya peningkatan dimana nilai terendah siswa juga terjadi peningkatan pada tes awal 10, siklus I bernilai 20 dan siklus II menjadi 40. nilai tertinggi juga meningkat pada tes awal 82, siklus I 85 dan siklus II 100. Jumlah siswa yang tuntas juga adanya peningkatan pada tes awal, siklus I dan siklus II yaitu mulai dari 6 orang siswa menjadi 14 orang siswa dari 14 orang menjadi 23 orang siswa. Pada siswa yang tidak tuntas

Cartesius: Jurnal Pendidikan Matematika Vol. 3, No. 1

CProdi Pendidikan Matematika Universitas Katolik Santo Thomas 
terjadi penurunan dari tes awal, siklus I sampai siklus II. Ketuntasan klasikal juga adanya peningkatan tes awal 23,07\%, disiklus I 53,84\% menjadi 88,46\%.

Dalam setiap siklus dilakukan observasi atau pengamatan kepada guru selama proses pembelajaran berlangsung. Pengamatan dilakukan oleh guru bidang studi matematika juga disebut sebagai pengamat atau observer pada penelitian. Observer memberikan penilaian kepada peneliti yang bertindak sebagai guru dengan mengisi lembar observasi aktivitas guru. Pada setiap siklus dilakukan observasi aktivitas guru sebanyak dua kali sesuai dengan pertemuan pada masing-masing siklus. Berikut tabel perbandingan hasil persentase observasi aktivitas guru pada siklus I dan siklus II:

Tabel 3. Observasi Aktivitas Guru pada Siklus I dan Siklus II

\begin{tabular}{lcccc}
\hline \multirow{2}{*}{ Pertemuan } & \multicolumn{2}{c}{ Siklus I } & \multicolumn{2}{c}{ Siklus II } \\
\cline { 2 - 5 } & Presentase & Kriteria & Presentase & Kriteria \\
\hline Pertama & $58 \%$ & Cukup & $79 \%$ & Baik \\
\hline Kedua & $72 \%$ & Baik & $88 \%$ & Sangat Baik \\
\hline $\begin{array}{l}\text { Rata-rata } \\
\text { Nilai }\end{array}$ & $\mathbf{6 5 \%}$ & Baik & $\mathbf{8 3 , 5 \%}$ & Sangat Baik \\
\hline
\end{tabular}

Dari tabel 3 dapat dilihat bahwa adanya peningkatan pada observasi aktivitas guru dalam siklus I dan siklus II. Pada siklus I rata-rata nilai observasi aktivitas guru yaitu 65\% dengan kriteria baik selanjutnya pada siklus II terjadi peningkatan menjadi 83,5\% dengan kriteria sangat baik.

Setiap dilakukan pengamatan terhadap siswa selama proses pembelajaran berlangsung. Pengamatan dilakukan oleh guru bidang studi matematika sebagai observer pada penelitian. Observer memberikan penilaian terhadap siswa dengan mengisi lembar observasi aktivitas siswa. Pada tiap siklus dilakukan observasi aktivitas siswa sebanyak dua kali sesuai dengan pertemuan pada tiap siklus. Perbandingan hasil persentase observasi aktivitas siswa pada siklus I dan siklus II sebagai berikut:

Cartesius: Jurnal Pendidikan Matematika Vol. 3, No. 1

CProdi Pendidikan Matematika Universitas Katolik Santo Thomas 
Tabel 4. Hasil Observasi Aktivitas Siswa pada Siklus I dan Siklus II

\begin{tabular}{lcccc}
\hline \multirow{2}{*}{ Pertemuan } & \multicolumn{2}{c}{ Siklus I } & \multicolumn{2}{c}{ Siklus II } \\
\cline { 2 - 5 } & Presentase & Kriteria & Presentase & Kriteria \\
\hline Pertama & $57 \%$ & Cukup & $76 \%$ & Baik \\
Kedua & $65 \%$ & Baik & $87 \%$ & Sangat Baik \\
\hline Rata-ata Nilai & $\mathbf{6 1 \%}$ & Baik & $\mathbf{8 1 , 5 \%}$ & Sangat Baik \\
\hline
\end{tabular}

Dari tabel 4 dapat dilihat bahwa adanya peningkatan hasil observasi aktivitas siswa pada siklus I dan Siklus II. Pada siklus I rata-rata nilai observasi aktivitas siswa yaitu $61 \%$ dengan kriteria baik kemudian pada siklus II terjadi peningkatan menjadi 81,5\% dengan kriteria sangat baik.

\section{KESIMPULAN}

Berdasarkan hasil analisis data dan hasil penelitian, diambil kesimpulan yang berkaitan dengan model pembelajaran Contextual Teaching and Learning (CTL) berbantuan aplikasi geometry calculator dapat meningkatkan kemampuan berpikir kritis matematis siswa, dapat dilihat dari penerapan model pembelajaran Contextual Teaching and Learning (CTL). Adapun data yang diperoleh sebelum dan sesudah pembelajaran disajikan sebagai berikut:

a. Sebelum pembelajaran dilakukan, diperoleh analisis data menunjukkan tingkat kemampuan berpikir kritis matematis siswa dengan persentase ketuntasan klasikal 23,07\%.

b. Setelah dilakukan tindakan dengan penerapan model pembelajaran Contextual Teaching and Learning (CTL) pada siklus I dan siklus II hasil analisis data kemampuan berpikir matematis siswa yaitu $53,84 \%$ dan $88,46 \%$.

c. Pelaksanaan pembelajaran melalui model pembelajaran contextual teaching and learning (CTL)pada materi segiempat dan segitiga sudah terlihat sangat baik yaitu dengan rata-rata di atas $75 \%$. Hal ini dapat dilihat dari lembar observasi aktivitas guru dan aktivitas siswa.

Dari hasil data yang diperoleh, dapat disimpulkan bahwa dengan menggunakan model pembelajaran Contextual Teaching and Learning (CTL) berbantuan aplikasi geometry calculator untuk meningkatkan kemampuan

Cartesius: Jurnal Pendidikan Matematika Vol. 3, No. 1

CProdi Pendidikan Matematika Universitas Katolik Santo Thomas 
berpikir kritis matematis siswa pada materi segiempat dan segitiga di kelas VII SMP Budi Murni 1 Medan dapat diterapkan dengan baik.

\section{UCAPAN TERIMAKASIH}

Penulis menyampaikan terimakasih kepada Bapak Arisan Candra Nainggolan, M.Pd. sebagai Dosen Pembimbing 1 dan Ibu Frida M. A. Simorangkir, S.Si., M.Pd. sebagai Dosen Pembimbing 2 yang telah mengarahkan dan membimbing penulis mulai dari awal penelitian hingga berakhirnya penelitian sehingga penulis dapat menuliskan artikel ini yang merupakan bagian dari hasil penelitian penulis. Penulis juga menyampaikan terimakasih kepada Kepala Program Studi Pendidikan Matematika, Dekan, dan Rektor Universitas Katolik Santo Thomas atas dukungan yang diberikan kepada penulis.

\section{DAFTAR PUSTAKA}

[1] Aqib. 2015. Model-Model Media dan Strategi Pembelajaran. Kontekstual. Bandung: Yrama Widya.

[2] Arikunto. 2010. Prosedur Penelitian Suatu Pendekatan Praktik. Jakarta: Rineka Cipta.

[3] Arikunto. 2013. Dasar - Dasar Evaluasi Pendidikan. Jakarta: Bumi Aksara. https://play.google.com/store/apps/details?id=com.famobix.geometryx \&hl=en US. Diakses tanggal 13 Februari 2019 pukul 19:35 wib.

[4] http://www.citrasatelit.com/kegunaan-calculate-geometry/ diakses 06 April 2019 pukul 14:35.

[5] Gita, Alexandra dan Novisita, Ratu. 2018. Profil Kemampuan Berpikir Kritis Matematis Siswa SMP dengan Graded Response Model. Jurnal Mosharafa. 7(1).

[6] Kunandar. 2010. Penilitian Tindakan Kelas. Jakarta: PT. Rajagrafindo Persada.

[7] Lestari, K.E dan Yudhanedara, M.R. 2015. Penelitian Pendidikan Matematika. Bandung: Refika Aditama.

Cartesius: Jurnal Pendidikan Matematika Vol. 3, No. 1

CProdi Pendidikan Matematika Universitas Katolik Santo Thomas 
[8] Mahmuzah. 2015. Peningkatan Kemampuan Berpikir Kritis Matematis Siswa Smp Melalui Pendekatan Problem Posing. Jurnal Peluang, 4(1).

[9] Novtiar, Chandra dan Aripin, Usman. 2017. Siswa Meningkatkan Kemampuan Berpikir Kritis Matematis dan Kepercayaan Diri SMP Melalui Pendekatan Open Ended. Jurnal PRISMA Universitas Suryakancana. VI(2).

[10] Nababan, Lizon dan Zulkifli. 2015. Pengaruh Penerapan Strategi Pembelajaran Kontekstual (Contextual Teaching and Learning) Terhadap Hasil Belajar Ilmu Bahan Bangunan Siswa Kelas X Program Keahlian Konstruksi Batu Beton SMK Negeri 1 Lintongnihuta. Jurnal Educational Building. 1(2). Hal.188.

[11] Panjaitan, M.A dan Hasibuan, E.A. 2018. Penerapan Model Pembelajaran Contextual Teaching and Learning (CTL) Terhadap Kemampuan Berpikir Kritis Matematika Siswa Kelas VIII Di SMP Negeri 10 Padang Sidimpuan. Jurnal Penelitian dan Pembelajaran MIPA. 3(2).

[12] Pafitriani, Nur. 2015. Penerapan Model Pembelajaran Kontekstual untuk Meningkatkan Kemampuan Berpikir Kritis Matematika Pada Siswa Kelas IV A SD N Margoyasan. FKIP Universitas Negeri Yogyakarta: Yogyakarta.

[13] Rusman. 2017. Belajar \& Pembelajaran. Bandung: Kencana.

[14] Saiful, Bahri. 2017. Pengaruh Penerapan Model Pembelajaran Contextual Teaching And Learning (CTL) Tipe Inquiry Terhadap Kemampuan Berpikir Kritis. Jurnal Pendidikan Islam. 8(1).

[15] Sanjaya, Wina. 2013. Penelitian Pendidikan. Jakarta: Kencana

[16] Sanjaya, Wina. 2013. Penelitian Tindakan Kelas. Jakarta: Kencana

[17] Sari, D.A. 2018. Pembelajaran Matematika Menggunakan Model Contextual Teaching and Learning (CTL) Pada Materi Kubus Dengan Konteks Tahu di Kelas VIII. Journal of Dedicators Community UNISNU Jepara. 2(2).

[18] Sapitri, N.M. 2017. Penerapan Pembelajaran Kontekstual Untuk Meningkatkan Kemampuan Berpikir Kritis Matematis dan Self Confidence Siswa. IKIP Bandar Lampung: Bandar Lampung.

Cartesius: Jurnal Pendidikan Matematika Vol. 3, No. 1

CProdi Pendidikan Matematika Universitas Katolik Santo Thomas 
[19] Setiawan, R. 2017. Penelitian Tindakan Kelas (Action Research).Yogyakarta: Nuha Medika.

[20] Shoimin, Aris. 2016. 68 Model Pembelajaran INOVATIF dalam Kurikulum 2013. Yogyakarta: Ar-Ruzz Media.

[21] Sianturi, April dkk. 2018. Pengaruh Model Problem Based Learning (PBL) Terhadap Kemampuan Berpikir Kritis Matematis Siswa SMPN 5 Sumbul. Jurnal UNION: Jurnal Pendidikan Matematika. 6(1).

[22] Soemarmo, Utari. 2014. Penilaian Pembelajaran Matematika. Bandung: PT Refika Aditama.

[23] Sudjana, Nana. 2016. Penilaian Hasil Proses Belajar Mengajar. Bandung: PT. Remaja Rosdakarya Offset.

[24] Susanto, Ahmad. 2014. Teori Belajar dan Pembelajaran di Sekolah Dasar. Jakarta: Kencana Prenada Media Group.

[25] Wakijo dan Suprihatin, Siti. 2016. Implementasi Pendekatan Contextual Teaching And Learning (Ctl) Terhadap Kemampuan Berpikir Kritis Siswa. Jurnal Promosi. 4(2).

[26] Tampubolon, Saur. 2014. Penelitian Tindakan Kelas Sebagai Pengembangan Profesi Pendidik dan Keilmuan. Jakarta: Erlangga

[27] T. Jumaisyaroh1, E.E. Napitupulu, dan Hasratuddin. 2014. Peningkatan Kemampuan Berpikir Kritis Matematis dan Kemandirian Belajar Siswa SMP melalui Pembelajaran Berbasis Masalah. Jurnal Kreano. 5(2). 